\author{
Andrii Kutsyk \\ Wschodnioeuropejski Uniwersytet Narodowy im. Łesi Ukrainki \\ ORCID: 0000-0001-7032-5984
}

\title{
Evolution of human cultural development within the context of the establishment of the Internet
}

\begin{abstract}
This article examines the evolution of the emergence of the Internet. It is shown how at first people created networks, and how subsequently the network became the influencer of human life. Conditional stages of formation of web culture as well as of that of values of network computer communication are characterized. It is highlighted what led to the origination of freedom of information. The transition from the non-commercial nature of the content to commerce and the mass of the Internet are also discussed. The development of Web 2.0 culture, which includes blogs, electronic encyclopaedias and social networks, is analysed. Finally, it's shown how web 2.0 has become an integral part of the existence of the human-generation web culture. Also, the benchmark for Web 1.0 and Web 2.0 is described in Tim O Reilly's article „What is Web 2.0?» It shows why and how blogs began, and what the subculture of bloggers do today. Additionally, the special role of video hosting Your Tube in the progress of the Internet is discussed, namely describing how YouTube has transitioned from a personal video hosting service towards a replacement for Television itself.Finally, the importance of social networks, which have become an interactive platform, that combines the ability to view videos, photos and communication in a single forum was also highlighted.
\end{abstract}

Keywords: cultural cultivating, web culture, network communication, collective intelligence, information freedom, Web 2.0.

\section{Ewolucja kulturologiczna człowieka w kontekście rozwoju Internetu}

\section{Streszczenie}

W artykule omówiono ewolucję pojawienia się Internetu. Pokazano, jak człowiek zaczął tworzyć sieć, a później sieć stała się twórcą ludzkiego życia. Scharakteryzowano etapy poustawania kultury internetowej i kształtowania wartości sieciowej komunikacji komputerowej, a także przybliżono drogę ku wolności informacji oraz od niekomercyjnego charakteru sieci do komercyjnego i masowego Internetu. Analizując rozwój kultury Web 2.0, która obejmuje blogi, encyklopedię elektroniczną i sieci społecznościoue ukazano, w jaki sposób Web 2.0 stał się integralną częścią kultury internetowej. Ponadto Web 1.0 i Web 2.0 opisano w artykule Tima O'Reilly'ego „Co to jest Web 2.0?”, który pokazuje, dlaczego i jak blogowanie się zaczęło i co robi dziś subkultura blogów. Omówiono także specjalną rolę wideo hostingu YouTube w rozwoju Internetu, a mianowicie jak YouTube przeniósł się z osobistego hostingu wideo, aby zastąpić telewizor. Na koniec 
Andrii Kutsyk

podkreślono znaczenie sieci społecznościouych, które stały się interaktywną platformą łączącą możliwość oglądania filmów, zdjęć i komunikacji na jednej platformie.

Słowa kluWzowe: tworzenie kultury, kultura internetowa, komunikacja sieciowa, inteligencja zbiorowa, wolność informacji, web 2.0.

\section{Presenting main material}

The Internet network, which emerged in the 1970's to meet the needs of the military has now become not only a new technical invention, but also a new cultural phenomenon that has spread its influence on people. It has become a part of life, and subsequently has become a new cultural space by the use of the network as a means.

The history of the development of the Internet is not just a story of one technology, such as television or radio. This is a story of a new paradigm of socio-cultural life, where technology is combined with culture and society. Confirmation of my words can be cited by media researcher M. Castells. "The Internet is an information technology and a social form that contains the information age in the same way as an electric motor was the lever of social and technical changes in the industrial era". ${ }^{1}$ This quotation may indicate that today the Internet (for the 21st century) is the driving force of social and technological change, transforming a person as such, and simultaneously making the person the driver of the mentioned change.

If we look at the statistics of the number of users of the Internet network, from the beginning of its operation to the present day, the numbers are truly impressive. According to the portal of world Internet statistics Internet World Stat ${ }^{2}$, in 1995, the number of Internet users in the world was 16 million, in 2005, 1 billion, on June 30,2018 , the number of Internet users reached 4,208,571,287, that is, it is more than $1 / 3$ of the general population of mankind $(7,634,758,428)^{3}$. From these statistics, we can see how rapidly the popularity of the network grew in the late 90's. But we can also observe that the largest development network has been in the period since 2005 to this day, when social networks appeared, and computers (or other gadgets) and the Internet became one single entity. Today, there is not a single computer or phone that does not support Internet functions.

Analysing the evolution of the Internet, and with it and the possibility of its cultural impact, it is necessary to remember and analyse how the network was created and the stages through which it went. So researcher Tsareva A., in his article "People on the Net: A Changing Web Generation" highlighted and substantiated the stages

\footnotetext{
${ }^{1}$ M. Kastel's, Stanovlenie obshhestva setevyh struktur. Novaja postindustrial'naja volna na Zapade: Antologija, ed. B.JI. Inozemceva. - M.: Academia 1990.

2 World internet usage and population statistics, https://www.internetworldstats.com/stats.htm (access date: 30.06.2018).

${ }^{3}$ Ibidem.
} 
of the development of the network, conventionally calling them "creators", "users" and "connected".

You can agree with the conventional names of the periods of network development, since the history of network creation and development is rather heterogeneous. It was initially not oriented to the masses and commerce. The purpose of the "creators" of the Internet in the person of Joseph Lyclider (head of the agency of advanced defence research projects of the USA) was the creation of an electronic data transmission system in the event of a threat of war.

All this was done quickly by using the programmers of the four largest research centres in the United States: California University of Los Angeles, Stanford Research Centre, University of Utah and the University of California, Santa Barbara. On September 1, 1969, the first server, ARPANET, was established at the University of California Los Angeles. ${ }^{6}$

From this moment two evolutionary cultural events were created, the first is the creation of the Internet itself, and the second is its decentrality. That is, the Internet has become a network of networks, without a single centre (server). Later philosophers, Deleuze J., and Guattari F., in their work "Thousand Plateau. Capitalism and schizophrenia" introduce the concept of rhizomes. Rhizome is a rhizome, but without central roots. ${ }^{7}$ That is, it is the same Internet network, which has grown as a rhizome, but does not have a central root which, if desired, could be destroyed. The main and important result of this evolutionary event is that now the information cannot be destroyed, and from this moment the information itself becomes indelible.

Another important step in the evolution of the network was the creation of e-mail by American programmer Ray Thomlinson. He also used for the first time the "@” badge, for separating the user name and computer from the e-mail ${ }^{8}$. Letters that usually waited a week, a month or maybe years, now could be obtained instantly with the presence of a computer and the Internet.

Now, for scientists, the question arises to make the Internet and electronic mail, as its inalienable element, more real or „alive”. It was important that someone reading an e-mail, felt the emotions with which it was written. Kevin McKenzie in 1979 created the first emotion of e-mail, which looked like: "-)". The idea was instantly picked up and developed by other programmers. Eric Raymond made the greatest effort to its creation and development, he first introduced the notion of a "hacker" and furthermore

\footnotetext{
${ }^{4}$ A. Tsareva., Lyudy`na v merezhi: zmina veb-pokolin`, „Merezheve suspil`stvo ta merezhevi spil`noty'”2012, No. 6, p. 36-54.

5 Joseph Carl Robnett Licklider, https://pl.wikipedia.org/wiki/Joseph_Carl_Robnett_Licklider (access date: 24..01.2014).

${ }^{6}$ internet, istoriya, https://uk.wikipedia.org/wiki/\%D0\%86\%D0\%BD\%D1\%82\%D0\%B5\%D1\% 80\%D0\%BD\%D0\%B5\%D1\%82 (access date: 30.10.2018).

${ }^{7}$ G. Deleuze, F. Guattari, Capitalisme et schizophrénie, L'Anti-CEdipe, Les Editions de minuit; France 1972.

8 Raymond Samuel Tomlinson, https://pl.wikipedia.org/wiki/Ray_Tomlinson (access date: 21.10. 2018).
} 
created a hacker's dictionary, also known as the "Jargon File". At the same time, in this dictionary three other signs are introduced for use in emails: ": -) Joke", ":) Smile”, ,:(Sad”.

Since then, virtual communication has begun to emerge, which is so well known to us today. E-mail is sent to advertisements of various content, wishing to receive none. This type of advertising has been called spam, and people who make it "spammers". Also, along with spam, there are other types of communications such as trolling, flooding (i.e. sending someone useless emails in order to clutter their inbox). All these methods are aimed at provoking discussion in the network, but additionally cause negative emotional responses in the recipient.

There are also various programs to destroy already existing programs and information. They are called computer viruses and are divided into several types. Namely the "wrecker", "destroyer", "worm" and "Joke", each one has its function from the complete obliteration of the program or information to the usual intimidation of the user ${ }^{10}$. It should be noted that the chronological time is the 90 's and it is at this time that the Internet began to shift from non-commercialization to mass-commercialization. The period from the 90's to the 00's is called by the media researcher Tsareva A., as the "Generation of Consumers", since users started to consume, and this in turn lead to the further evolution of the network ${ }^{11}$.

The Internet is used to meet various life needs such as leisure, training and networking. Online stores like Amazon (1995), eBay (1995): an online auction where you can sell and buy items, Yahoo's first online classified ads service and Craigslist (1995) began to appear.

The culmination of the development of the Internet of this period is the creation of a Google search engine. The task of which is to systematize and distribute information available on the internet.

Google has emerged as a technological and cultural phenomenon that is trying to move the real world to the virtual: It processes more than 1 billion requests per day. ${ }^{12}$ So it has digitized all possible and accessible books, literature of absolutely different content, as well as our space.

A Google maps service has also been created, which is filled with satellite imagery and maps from around the world. It is used to view any city and street, get directions to a location via GPS (Global Positioning System). Together with Google maps, there is also a free e-mail service ("Gmail") and an online dictionary as well as translator called Google translate.

As a result, Google has become a database of people's intent to find information. Along with the positive development of this search system, this technological tsunami

\footnotetext{
${ }_{9}$ Jargon File, https://pl.wikipedia.org/wiki/Jargon_File (access date: 14.01. 2018).

${ }^{10}$ Komp'yuterny j virus, https://uk.wikipedia.org/wiki/\%D0\%9A\%D0\%BE\%D0\%BC\%D0\%BF\%27\%D1\%8E\%D1\%82\%D0\%B5\%D1\%80\%D0\%BD\%D0\%B8\%D0\%B9_\%D0\%B2\%D1\%96\%D1 \%80\%D1\%83\%D1\%81 (access date: 16.11. 2018).

11 A. Tsareva, Lyudy'na v merezhi: zmina veb-pokolin', op. cit.

12 Google Inc., https://uk.wikipedia.org/wiki/Google (access date: 10.12. 2018).
} 
creates a monopoly of power on the Internet. We can say even more, this power is exercised on every user of the search engine. After all, what you are looking for can also cause addiction, deviant behaviour and in general bring you into the world of pop culture, part of which the search engine Google has become.

The emergence of online stores, online media, web chats and the Google system, which has become a tool for the search and use of information, has created a new form of identity. This is the identity of a virtual person who prefers reality without censorship and anonymous communication.

Internet media researcher Tsareva A., noted that the information freedom and anonymity of communication received, led to the formation of new values in a person of that period. The flow of traffic becomes a value, focusing on what is happening "here and now"; the possibility of "games with identity", designing, approbation and modification of virtual network masks in the public space and the freedom to disseminate information regardless of its content and quality ${ }^{13}$.

It would seem that man has created a new era and there is nowhere to go, but the history of information technology, along with the cultural space, stubbornly shows us that there is no end to human ingenuity. Then there is Tim O'Reilly ${ }^{14}$, with his concept of Web 2.0, which completely changes the system of creating an internet culture. In fact, the philosophy of the Internet, for which the user begins to act as a co-developer of the content, changes.

Previously, the whole system of the network acted as a source for streamlining and submitting information, and now communication begins to come to the forefront.

Tim O'Reilly in his article "What is Web 2.0", for a better understanding of his concept, gives a comparative table between Web 1.0 and Web 2.0. ${ }^{15}$

\begin{tabular}{|r|l|}
\hline Web 1.0 & Web 2.0 \\
\hline DoubleClick & Google AdSense \\
Ofoto & Flickr \\
Akamai & BitTorrent \\
mp3.com & Napster \\
Britannica Online & Wikipedia \\
personal websites & blogging \\
evite & upcoming.org and EVDB \\
domain name speculation & search engine optimization \\
page vieus & cost per click \\
screen scraping & web services \\
publishing & participation \\
content management systems & wikis \\
directories (taxonomy) & tagging (,folksonomy”) \\
stickiness & syndication \\
\hline
\end{tabular}

\footnotetext{
${ }^{13}$ A. Tsareva, Lyudy'na v merezhi: zmina veb-pokolin', op. cit.

14 About O'Reilly, https://wuw.oreilly.com/tim/ (access date: 10.03.2019).

${ }^{15}$ Ibidem.
} 
If we analyse the above table it becomes obvious that Web 2.0 stands out in three aspects. Firstly in the creation of Wikipedia, when each willing person can independently create, fill out and edit content.

Also, the era of Web 2.0 has led to the creation of personalized pages on various information websites, known as - Blogs. People began to introduce their personal blogs, which are very similar to online diaries, which describe their vieus on this or that event, the life of the country, or in general, the quality of philosophical ideas, reflections on life. The first ever blog can be considered as a brainchild of Tim Berners-Lee ${ }^{16}$, where he began to post various news.

To date, blogs have become so popular that many researchers have identified a separate subculture of bloggers. ${ }^{17}$ This subculture plays the role of a particular intermediary (medium) between people, because it provides feedback, such as e-mail, commenting facility on various forums and chats. Also, using the blog page, you can publish text-rich text, articles that are difficult to do in the same social networks, where people focus primarily on short texts with pronounced images.

A new wave of blogging, the creation of the YouTube platform launched the video blogging system. Now everyone can create a YouTube channel, and there's their video blogging on any topic, when this channel gains a lot of vieus, the user can attract ads and receive dividends from their content. This video hosting was so popular that many journalists who worked for different TV channels and received censorship on their product, now have an uncensored platform, and are able to make a quality product in some cases for higher fees (mostly from advertising).

It can also be argued that in the future not only individual journalism will go online but also all other forms of entertainment including television, it won't be too farfetched to say that approximately 10 years from now, the Internet and YouTube will completely replace television.

The most noteworthy development of Web 2.0 has been the creation of the social network. The social network combines all that was previously mentioned. This also applies to the search and receipt of systematic information, e-mail functions, blogging, and of course the communication that has become its foundation.

Although with all the universality of the above-mentioned and substantiated positive Web 2.0 creation, the American media researcher, the man who introduced the term „Virtual Real", Jaron Lanier criticizes the web 2.0 system. In his book "You Are Not a Gadget," he characterizes Web 2.0.: "Something like missionary reductionism has happened to the internet with the rise of web 2.0. The strangeness is being leached away by the mush-making process. Individual web pages as they first appeared in the early 1990S had the flavour of personhood. MySpace preserved some of that flavour, though the process of regularized formatting had begun. Facebook went further, organizing

\footnotetext{
${ }^{16}$ Sir Timothy John Berners-Lee, https://en.wikipedia.org/wiki/Tim_Berners-Lee (access date: 12.01.2019).

${ }_{17}$ Blogosphere, https://en.wikipedia.org/wiki/Blogosphere (access date: 05.12.2018).
} 
people into multiple-choice identities, while Wikipedia seeks to erase point of view entirely". ${ }^{18}$

Thus, the researcher emphasizes that with the advent of Web 2.0, and especially social networks and Wikipedia, a person begins to lose themselves as a personality and these sites subtly erase the opportunity to express different points of view.

Thus, we can conclude that the evolution of human cultural development in the context of the development of the Internet network was a phenomenon that combined changes in the technological, cultural and social life of mankind.

The system, created as a purely technological phenomenon for military purposes, has become a phenomenon being the subculture on its own. So the Internet was created by a person, and then the Internet began to influence a person, their work, leisure and hobbies. At the beginning of its development, the network was created and used by highly educated programmers, who tried every day to make new innovations to this forum.

Later in the 70-80s, the network was used only as a space for thematic communications and the exchange of important information. This was facilitated by the creation of e-mail as an instrument.

In the first stage of the development of a network, a person creates a culture of free information, promotes the basis of non-commercial activity, and the value of collective intelligence comes to the fore. Also, network communication is mainly due to the use of nicknames and the so-called nickname.

When Internet Markets, online media, and the ad services appear, people start to live in a virtual reality, and the stage of network commercialization begins. The Internet is becoming massive as its consumers increase, everyone is beginning to understand its economic factor. Also, an important place at this stage in creating the culture of the Internet is occupied by young people, since most of the content is directed at this demographic in particular, especially with regard to online games.

The creation of Google and Web 2.0 summarizes the evolution of the person of the network, and shows how the networks began to control and influence a person. After all, the product of the creation of Web 2.0, Wikipedia, YouTube, blogs and social networks have become a personal space without which human life today becomes impossible.

\section{References}

About O’Reilly, https://wuw.oreilly.com/tim/ (access date: 10.03.2019).

Blogosphere, https://en.wikipedia.org/wiki/Blogosphere (access date: 5.12.2018).

Deleuze G., Guattari F., Capitalisme et schizophrénie. L’Anti-CEdipe, Les Editions de minuit, France 1972.

Google Inc., https://uk.wikipedia.org/wiki/Google (access date: 10.12.2018).

${ }_{18}$ J. Lanier, You Are Not a Gadget: A Manifesto, Alfred A. Knopf, New York 2010, p. 30. 
Andrii Kutsyk

Internet, istoriya, https://uk.wikipedia.org/wiki/\%D0\%86\%D0\%BD\%D1\%82\%D0\%B5\%D1\%80\% D0\%BD\%D0\%B5\%D1\%82 (access date: 30.10.2018).

Jargon File, https://pl.wikipedia.org/wiki/Jargon_File (access date: 14.01.2018).

Joseph Carl Robnett Licklider, https://pl.wikipedia.org/wiki/Joseph_Carl_Robnett_Licklider (access date: 24..01.2014).

Kastel's M., Stanovlenie obshhestva setevyh struktur. Novaja postindustrial'naja volna na Zapade: Antologija, ed. B.JI. Inozemceva. - M.: Academia, 1990.

Komp'yuterny'j virus, https://uk.wikipedia.org/wiki/\%D0\%9A\%D0\%BE\%D0\%BC\%D0\%BF\%27\%D1\%8E\%D1\%82\%D0\%B5\%D1\%80\%D0\%BD\%D0\%B8\%D0\%B9_\%D0\%B2\%D1\%96\% D1\%80\%D1\%83\%D1\%81 (access date: 16.11.2018).

Lanier J., You Are Not a Gadget: A Manifesto, Alfred A. Knopf, New York 2010.

Raymond Samuel Tomlinson, https://pl.wikipedia.org/wiki/Ray_Tomlinson (access date: 21.10.2018).

Sir Timothy John Berners-Lee, https://en.wikipedia.org/wiki/Tim_Berners-Lee (access date: 12.01.2019).

Tsareva A., Lyudy'na v merezhi: zmina veb-pokolin', "Merezheve suspil'stvo ta merezhevi spil'noty"' 2012, No. 6, p. 36-54.

World internet usage and population statistics, https://www.internetworldstats.com/stats.htm (access date: 30.06.2018). 